(c) American Dairy Science Association, 2005.

\title{
Corn Grain Endosperm Type and Brown Midrib 3 Corn Silage: Site of Digestion and Ruminal Digestion Kinetics in Lactating Cows
}

\author{
C. C. Taylor and M. S. Allen \\ Department of Animal Science, Michigan State University, East Lansing 48824-1225
}

\begin{abstract}
Interactions of endosperm type of corn grain and the brown midrib $3(\mathrm{bm} 3)$ mutation in corn silage on ruminal kinetics and site of nutrient digestion of lactating dairy cows were evaluated. Eight ruminally and duodenally cannulated cows ( $72 \pm 8 \mathrm{~d}$ in milk; mean $\pm \mathrm{SD}$ ) were used in a duplicated $4 \times 4$ Latin square design experiment with a $2 \times 2$ factorial arrangement of treatments. Treatments were corn grain endosperm type (floury or vitreous) and corn silage type ( $\mathrm{bm} 3$ or isogenic normal). Diets contained 26\% neutral detergent fiber (NDF) and $30 \%$ starch. Interactions of treatments were not observed for any measure of digestibility, but digestion kinetics of starch and fiber did interact to affect digestible organic matter intake by affecting dry matter intake. Rate of ruminal starch digestion was faster and rate of ruminal starch passage tended to be slower in diets containing corn grain with floury vs. vitreous endosperm, resulting in a mean increase of 22 units for ruminal starch digestibility. Although compensatory postruminal starch digestion decreased differences among treatments for total tract starch digestibility, starch entering the duodenum was more digestible for grain with floury endosperm compared with vitreous grain, resulting in greater total tract starch digestibility for floury compared with vitreous corn grain. Fermentation rate of potentially digestible NDF was not affected by either $b m 3$ corn silage or greater ruminal starch digestion of floury grain. Brown midrib corn silage increased total tract NDF digestibility vs. control silage by numerically increasing ruminal and postruminal digestibility of NDF. Endosperm type of corn grain greatly influences site of starch digestion and should be considered when formulating diets.
\end{abstract}

(Key words: endosperm, brown midrib, starch digestibility)

Abbreviation key: bm3 = brown midrib 3 mutation, iNDF = indigestible NDF, $\mathbf{p d N D F}=$ potentially digestible NDF.

Received September 8, 2004.

Accepted December 10, 2004.

Corresponding author: Michael S. Allen; e-mail: allenm@msu.edu.

\section{INTRODUCTION}

Ruminants have dietary requirements for forage to maximize production and ruminal health, but slower digestion and greater ruminal retention time of fiber can potentially limit DMI and milk yield. The brown midrib 3 mutation (bm3) in corn silage increases potential digestibility of fiber and allows for greater feed intake while providing forage fiber (Oba and Allen, 2000a). Although increased fiber digestibility can reduce the filling effect of fibrous feeds and might allow greater feed intake, $b m 3$ corn silage reduces ruminal $\mathrm{pH}$ and might reduce ruminal digestibility of potentially digestible NDF (pdNDF; Oba and Allen, 2000b).

Brown midrib 3 corn silage also reduced ruminal starch digestibility compared with its isogenic control corn silage because of greater ruminal starch passage rate in bm3 corn silage diets (Oba and Allen, 2000b). This research indicates that $b m 3$ corn silage not only changes fiber digestibility but also has the potential to affect ruminal starch digestibility and thus site of starch digestion. Site of starch digestion can be manipulated by grain conservation method (Oba and Allen, 2003b), method of processing (Callison et al., 2001), and endosperm type of corn grain (Philippeau et al., 1999b). Flint corn, which has a higher proportion of vitreous endosperm, was digested more slowly and to a lesser extent than dent corn in the rumen of beef steers (Philippeau et al., 1999b). Endosperm type of corn grain varies widely across commercially available hybrids but is not considered when formulating diets for lactating dairy cows. Understanding how feedstuffs affect site of starch digestion is critical to commercial dairy production because manipulating site of starch digestion can alter feed intake (Allen, 2000), and ultimately milk production.

Controversy exists as to the benefits of ruminal vs. postruminal starch digestion. Ruminal starch digestion is needed to provide substrate for microbial growth and propionate as a glucose precursor for milk synthesis but can reduce ruminal $\mathrm{pH}$ and inhibit fiber digestibility if starch fermentation is too rapid. If ruminal starch degradation is too rapid, flux of propionate to the liver might limit DMI if it is oxidized rather than used for gluconeogenesis (Oba and Allen, 2003c). Shifting starch 
digestion to the intestines can theoretically provide more glucose to the animal but infusion experiments have suggested that increasing small intestinal glucose absorption may not increase glucose available for milk production (Knowlton et al., 1998; Arieli et al., 2001). Instead, increased glucose may be used for tissue retention (Reynolds et al., 2001) or may be oxidized to $\mathrm{CO}_{2}$ (Knowlton et al., 1998). It is important to understand how chemical and structural aspects of dietary ingredients can affect starch and fiber digestibility and how they interact to affect ruminal kinetics and site of nutrient digestion.

We hypothesized that corn grain with floury endosperm is more rapidly degraded in the rumen compared with corn grain with vitreous endosperm and will decrease rate of digestion of pdNDF to a greater extent when combined with bm 3 corn silage compared with control corn silage. Furthermore, ruminal passage rate of starch will be increased by $b m 3$ corn silage compared with control corn silage. The objective of this experiment was to evaluate interactions of the brown midrib 3 mutation in corn silage and corn grain endosperm type on site of nutrient digestion and ruminal digestion kinetics in lactating dairy cows.

\section{MATERIALS AND METHODS}

This article is the first of 3 articles in a series from one experiment that evaluated effects of corn grain endosperm type and the brown midrib 3 mutation in corn silage. This article discusses treatment effects on site of nutrient digestion and ruminal digestion kinetics, and the companion articles focus on feeding behavior and milk production (Taylor and Allen, 2005a) and ruminal fermentation and microbial $\mathrm{N}$ efficiency (Taylor and Allen, 2005b). Experimental procedures were approved by the All University Committee on Animal Use and Care at Michigan State University.

\section{Cows and Treatments}

Eight multiparous Holstein cows (72 \pm 8 DIM; mean \pm SD) from the Michigan State University Dairy Cattle Teaching and Research Center were assigned randomly to treatment sequence within duplicate $4 \times 4$ Latin squares balanced for carryover effects. A $2 \times 2$ factorial arrangement of treatments was used with main effects of corn grain endosperm type (floury or vitreous) and bm3 mutation in corn silage (present or absent). Treatment periods were $21 \mathrm{~d}$, consisting of an 11-d diet adaptation period followed by $10 \mathrm{~d}$ of collection. Surgical preparation of ruminally and duodenally cannulated cows was performed after dry-off, approximately $50 \mathrm{~d}$ before calving. Duodenal cannulas were soft gutter type made of Tygon and vinyl tubing (Crocker et al., 1998). For each animal, the duodenum was fistulated distal to the pylorus region before the pancreatic duct, and the cannula was placed between 10th and 11th ribs as described by Robinson et al. (1985). Surgery was performed at the Department of Large Animal Clinical Science, College of Veterinary Medicine, Michigan State University. At the beginning of the experiment, empty body weight (ruminal digesta removed) of cows was $531.8 \pm 43.9 \mathrm{~kg}$ (mean $\pm \mathrm{SD}$ ).

Two corn hybrids, 6208FQ and 657 (Cargill Hybrid Seeds, Minneapolis, MN), were planted for silage in the spring of 2001 at the Michigan State University Research Farm. The hybrids are isogenic except that Cargill 657 contains the $b m 3$ mutation. Cargill $6208 \mathrm{FQ}$ corn forage was harvested at $30.6 \%$ whole plant DM and chopped to 11-mm theoretical length of cut. Cargill 657 corn forage was harvested at $32.2 \%$ whole plant $\mathrm{DM}$ and chopped to $10-\mathrm{mm}$ theoretical length of cut. The chop lengths of the 2 hybrids differed to achieve a similar particle size distribution as measured using a Penn State Particle Size Separator (Lammers et al., 1996). Both hybrids were ensiled in 12.4-m diameter $\mathrm{AgBags}$ oriented in a west to east direction; silage was removed from the east end to minimize the effects of wind on silage DM. Nutrient compositions and physical characteristics of the corn silage treatments used in the experiment are shown in Table 1.

Two corn hybrids varying in endosperm type (floury and vitreous) were planted for grain in the spring of 2001 at the Michigan State University Research Farm. The floury (SL53; Crow's Hybrid Corn Company, Kentland, IN) and vitreous (Z75W; Wilson Genetics, Harlan, IA) hybrids were selected based upon their high and low in vitro starch digestibility, respectively. Grains were harvested after field drying to $\sim 20 \% \mathrm{DM}$, and were commercially dried at low temperature $\left(<32^{\circ} \mathrm{C}\right)$ to $\sim 14 \%$ DM. The corn was ground and bagged for use in the experiment. Vitreousness (\% of endosperm) for floury and vitreous corn grain was 3.0 and $67.2 \%$, respectively (Table 2). Nutrient compositions and physical characteristics of the corn grain treatments used in the experiment are shown in Table 2.

Experimental diets contained dry ground corn treatments (floury or vitreous), corn silage (bm3 or isogenic normal), alfalfa silage ( $10 \%$ of diet DM), whole linted cottonseed (7\% of diet DM), a protein supplement premix (soybean meal, distillers grains, and blood meal), and a premix of minerals and vitamins. Experimental diets were fed as TMR and were formulated to contain $27 \% \mathrm{NDF}, 18 \% \mathrm{CP}$, and minerals and vitamins to meet requirements according to NRC (2001). Ingredient and nutrient compositions of the experimental diets are shown in Table 3. 
Table 1. Nutrient compositions and physical characteristics of corn silages used to formulate experimental diets. ${ }^{1}$

\begin{tabular}{|c|c|c|c|}
\hline & Control & $b m 3^{2}$ & SEM \\
\hline $\mathrm{DM}, \%$ (oven dried at $55^{\circ} \mathrm{C}$ ) & $30.5^{\mathrm{b}}$ & $31.5^{\mathrm{a}}$ & 0.3 \\
\hline $\mathrm{NDF}$ & $41.2^{\mathrm{a}}$ & $38.9^{\mathrm{b}}$ & 0.5 \\
\hline $\mathrm{ADF}$ & $24.4^{\mathrm{a}}$ & $22.2^{\mathrm{b}}$ & 0.3 \\
\hline Lignin & $2.25^{\mathrm{a}}$ & $1.22^{\mathrm{b}}$ & 0.1 \\
\hline Starch & 25.8 & 26.6 & 0.5 \\
\hline $\mathrm{CP}$ & 7.70 & 8.30 & 0.3 \\
\hline Ether extract & 3.52 & 3.01 & 0.23 \\
\hline Ash & 2.96 & 3.32 & 0.2 \\
\hline Acetate & $1.49^{\mathrm{a}}$ & $1.29^{\mathrm{b}}$ & 0.04 \\
\hline Propionate & 0.12 & 0.10 & 0.01 \\
\hline Lactate & $5.67^{\mathrm{b}}$ & $5.95^{\mathrm{a}}$ & 0.07 \\
\hline Ethanol & 1.89 & 1.99 & 0.2 \\
\hline IV TDMD $^{3}$ & $79.5^{\mathrm{b}}$ & $87.1^{\mathrm{a}}$ & 0.26 \\
\hline IV NDFD, ${ }^{4} \%$ of NDF & $54.0^{\mathrm{b}}$ & $66.6^{\mathrm{a}}$ & 0.69 \\
\hline $\mathrm{pH}$ & 3.78 & 3.77 & 0.01 \\
\hline \multicolumn{4}{|l|}{ Particle size $^{5}(\%$ of DM $)$} \\
\hline Top & 6.87 & 6.60 & 1.3 \\
\hline Middle & 69.9 & 69.0 & 0.84 \\
\hline Bottom & 23.0 & 24.1 & 0.85 \\
\hline
\end{tabular}

${ }^{\mathrm{a}, \mathrm{b}}$ Means for nutrient composition in the same row followed by different superscript letters differ $(P<0.05)$.

${ }^{1}$ Nutrient compositions of corn silages sampled each period $(\mathrm{n}=8$ for each silage) were compared by ANOVA.

${ }^{2} b m 3$ = Brown midrib 3 mutant for corn silage.

${ }^{3} \mathrm{IV}$ TDMD $=$ In vitro true DM digestibility estimated after $30 \mathrm{~h}$ of incubation.

${ }^{4} \mathrm{IV}$ NDFD $=$ In vitro NDF digestibility estimated after $30 \mathrm{~h}$ of incubation.

${ }^{5}$ Determined with Penn State Particle Separator (Lammers et al, 1996).

\section{Data and Sample Collection}

Throughout the experiment, cows were housed in tiestalls and fed once daily $(1100 \mathrm{~h})$ at $110 \%$ of expected intake. Amounts of feed offered and orts were weighed for each cow daily during the collection period. Samples of all diet ingredients $(0.5 \mathrm{~kg})$ and orts from each cow (12.5\%) were collected daily on d 12 to 18 and combined into 2 samples per period, representing the digestibility (d 12 to 14 ) and feeding behavior (d 15 to 18 ) subperiods.

Chromic oxide was used as a marker to estimate nutrient digestibility in the rumen and in the total tract. Gelatin capsules (1.5 oz., Tropac Inc., Airfield, NJ) containing $5 \mathrm{~g}$ of chromic oxide and approximately $4 \mathrm{~g}$ of ground spelt hulls were dosed through the ruminal cannula at 0400,1200 , and $2000 \mathrm{~h}$ (total of $15 \mathrm{~g}$ of $\mathrm{Cr}_{2} \mathrm{O}_{3}$ per d) from 7 to $14 \mathrm{~d}$ with a $3 \times$ priming dose on $\mathrm{d} 7$. Duodenal (1000 g), fecal (500 g), and rumen fluid samples $(100 \mathrm{~mL})$ were collected every $9 \mathrm{~h}$ from d 12 to 14 so that 8 samples were taken for each cow each period, representing every $3 \mathrm{~h}$ of a 24 -h period to account for diurnal variation. Digesta from 5 sites in the rumen was combined and strained to obtain rumen fluid. All
Table 2. Nutrient compositions and physical characteristics of corn grains used to formulate experimental diets. ${ }^{1}$

\begin{tabular}{|c|c|c|c|}
\hline & Floury & Vitreous & SEM \\
\hline $\mathrm{DM}, \%$ & 86.8 & 87.0 & 0.1 \\
\hline Starch & 73.4 & 72.1 & 0.80 \\
\hline NDF & $8.69^{\mathrm{a}}$ & $8.43^{\mathrm{b}}$ & 0.02 \\
\hline $\mathrm{CP}$ & $8.19^{\mathrm{b}}$ & $9.07^{\mathrm{a}}$ & 0.14 \\
\hline Ether extract & 4.81 & 5.02 & 0.15 \\
\hline Ash & 1.28 & 1.24 & 0.04 \\
\hline IVSD, ${ }^{2} \% / \mathrm{h}$ & 7.7 & 1.8 & \\
\hline Vitreousness, \% of endosperm & $3.0^{\mathrm{b}}$ & $67.2^{\mathrm{a}}$ & 1.9 \\
\hline \multicolumn{4}{|l|}{ Sieve aperture $(\mu \mathrm{m})$} \\
\hline 4750 & 0.1 & 0.3 & 0.1 \\
\hline 2369 & 4.5 & 5.5 & 0.4 \\
\hline 1180 & $51.7^{\mathrm{b}}$ & $66.5^{\mathrm{a}}$ & 1.1 \\
\hline 600 & $25.7^{\mathrm{a}}$ & $18.5^{\mathrm{b}}$ & 1.8 \\
\hline 300 & 11.2 & 7.5 & 1.2 \\
\hline 150 & 4.6 & 1.6 & 1.3 \\
\hline 75 & 2.0 & 0.0 & 1.1 \\
\hline pan & 0.1 & 0.0 & 0.1 \\
\hline Mean particle size ${ }^{3}(\mu \mathrm{m})$ & $1377^{\mathrm{b}}$ & $1594^{\mathrm{a}}$ & 12.7 \\
\hline Standard deviation particle size & $655^{\mathrm{b}}$ & $744^{\mathrm{a}}$ & 11.2 \\
\hline
\end{tabular}

${ }^{\mathrm{a}, \mathrm{b}}$ Means for nutrient composition in the same row followed by different superscript letters differ $(P<0.05)$.

${ }^{1}$ Nutrient compositions of corn grains sampled each period $(n=4$ for each grain) were compared by ANOVA.

${ }^{2}$ IVSD $=$ In vitro starch digestibility estimated after $24 \mathrm{~h}$ of incubation.

${ }^{3}$ Determined using sieve shaker (model RX-86, W. S. Tyler Inc., Gastonia, NC).

digesta and fecal samples were immediately frozen at $-20^{\circ} \mathrm{C}$ until processing.

Effect of treatment on rate of liquid passage was measured on d 19 using a pulse dose of cobalt EDTA (Allen et al., 2000). Cobalt EDTA was dosed $2 \mathrm{~h}$ after feeding. Rumen fluid was sampled immediately before dosing and at $0.5,1,1.5,2,2.5,3,3.5,4,4.5,5,5.5,6,6.5,7$, 7.5 , and $8 \mathrm{~h}$ after dosing. Samples were immediately frozen at $-20^{\circ} \mathrm{C}$.

Ruminal contents were evacuated manually through the ruminal cannula at $1500 \mathrm{~h}$ ( $4 \mathrm{~h}$ after feeding) on $\mathrm{d}$ 20 and at $0900 \mathrm{~h}$ ( $2 \mathrm{~h}$ before feeding) on $\mathrm{d} 21$ of each period. Total ruminal content mass and volume were determined. During evacuation, $10 \%$ aliquots of digesta were separated to allow accurate sampling. Aliquots were squeezed through a nylon screen (1-mm pore size) to separate into primarily solid and liquid phases. Samples were taken from both phases for determination of nutrient pool size and an additional liquid sample was taken to measure VFA concentration. All samples were frozen immediately at $-20^{\circ} \mathrm{C}$.

\section{Sample and Statistical Analyses}

Diet ingredients and orts were dried in a $55^{\circ} \mathrm{C}$ forcedair oven for $72 \mathrm{~h}$ and analyzed for DM concentration. All 
MA) as described by Oba and Allen (2003a). Corn silage particle size was determined on wet silage samples using the Penn State Particle Separator (Lammers et al., 1996). Corn grain was dry-sieved (sieve apertures: $4750,2360,1180,600,300,150$, and $75 \mu \mathrm{m}$, and bottom pan) using a sieve shaker (model RX-86, W. S. Tyler Inc., Gastonia, NC) for approximately 20 min until the bottom pan weight was constant and the mean particle size of the corn grain was calculated (ASAE, 1968). For determination of corn grain vitreousness, 10 whole kernels from each hybrid were weighed and kernels were dissected into germ, pericarp, and vitreous endosperm sections and individually weighed. Total endosperm (floury and vitreous) weight was determined by subtracting germ and pericarp weight from whole kernel weight; vitreousness (\% of total endosperm) was calculated by dividing vitreous endosperm weight by total endosperm weight.

Rumen fluid samples taken for measurement of rate of liquid passage were analyzed for cobalt concentration by flame atomic absorption spectrophotometry according to manufacturer's recommendations (SpectrAA 220/FS, Varian Australia Pty. Ltd., Mulgrave, Victoria, Australia). Rate of cobalt disappearance was determined by nonlinear regression (JMP Version 4, SAS Institute, Inc., Cary, NC) of its decline in concentration in rumen fluid over time after dosing using a one-pool, first-order model accounting for background cobalt concentration.

Diet ingredients, duodenal digesta, and feces were analyzed for concentrations of chromium. Samples were digested with phosphoric acid (Williams et al., 1962) and chromium was quantified by flame atomic absorption spectrometry (SpectrAA 220, Varian) according to the manufacturer's recommendations. Although we intended to use chromic oxide as an external marker in this experiment, an apparent liquid phase subsampling problem occurred and iNDF was chosen as a duodenal flow marker. Subsampling problems would not be expected in fecal samples but iNDF was used as a fecal flow marker for consistency. Duodenal and fecal DM flows calculated using chromic oxide were correlated with flows calculated using iNDF as a marker $(r=0.60$ and $r=0.79$, respectively). Nutrient intake was calculated using the amounts and compositions of feed offered and refused. Duodenal flow of microbial OM and starch was determined as described by Taylor and Allen (2005b), and truly ruminally degraded OM was calculated by subtracting duodenal flow of nonmicrobial OM from OM intake. Truly ruminally degraded starch was calculated by subtracting duodenal flow of nonmicrobial starch from starch intake. Ruminal pool sizes $(\mathrm{kg})$ of $\mathrm{OM}, \mathrm{NDF}$, iNDF, pdNDF, and starch were determined by multiplying the concentration of each component by the ruminal digesta DM mass $(\mathrm{kg})$. Turnover rate in the rumen, passage rate from the rumen, and ruminal digestion rate of each component $(\% / \mathrm{h})$ were calculated using the following equations:

Turnover rate in the rumen $(\% / \mathrm{h})=100$ $\times$ (intake of component/ruminal pool of component/24

Passage rate from the rumen $(\% / \mathrm{h})=100$

$\times$ (duodenal flow of component/ruminal pool of component)/24; and

Digestion rate in the rumen $(\% / \mathrm{h})=$ turnover rate in the rumen $(\% / \mathrm{h})$

- passage rate from the rumen $(\% / \mathrm{h})$.

All data were analyzed using the fit model procedure of JMP (Version 4, SAS Institute, Cary, NC) according to the following model:

$$
\mathrm{Y}_{\mathrm{ijk}}=\mu+\mathrm{C}_{\mathrm{i}}+\mathrm{P}_{\mathrm{j}}+\mathrm{T}_{\mathrm{k}}+\mathrm{PT}_{\mathrm{jk}}+\mathrm{e}_{\mathrm{ijk}}
$$

where $\mu$ = overall mean, $\mathrm{C}_{\mathrm{i}}=$ random effect of cow ( $\mathrm{i}=$ 1 to 8$), P_{j}=$ fixed effect of period ( $j=1$ to 4$), T_{k}=$ fixed effect of treatment ( $\mathrm{k}=1$ to 4$), \mathrm{PT}_{\mathrm{jk}}=$ interaction of period and treatment, and $\mathrm{e}_{\mathrm{ijk}}=$ residual.

A reduced model without period $\times$ treatment interactions was used when this effect was not significant $(P$ $>0.15$ ). Orthogonal contrasts were used to determine main effect of corn silage type, main effect of corn grain type, and the interaction of corn silage type and endosperm type of corn grain. Pearson correlation coefficients were determined between cow-period observations for some parameters. Main treatment effects and correlations were declared significant at $P<0.05$ and tendencies were declared at $P<0.10$. Interactions between treatments were declared significant at $P<0.10$ and tendencies were declared at $P<0.15$.

Data for one cow were removed from all statistical analyses due to clinical mastitis during the first period. This cow was replaced with a spare animal for the remaining 3 periods. Another cow developed pneumonia during the diet adaptation period of period 2 and was recovering during the first day of the collection period. Data for this cow were omitted from the digestibility subperiod of period 2 but were used from the feeding behavior subperiod as it had recovered sufficiently.

\section{RESULTS AND DISCUSSION}

\section{DM and OM Digestion}

No interactions between main treatment effects were found for any measure of DM or OM digestibility. Addi- 
Table 4. Effects of corn grain endosperm type and brown midrib 3 corn silage on digestion of DM and OM.

\begin{tabular}{|c|c|c|c|c|c|c|c|c|}
\hline & \multicolumn{2}{|c|}{ Control } & \multicolumn{2}{|c|}{ bm3 } & \multirow[b]{2}{*}{ SEM } & \multicolumn{3}{|c|}{$P$} \\
\hline & Floury & Vitreous & Floury & Vitreous & & $\mathrm{S}^{1}$ & $\mathrm{G}^{2}$ & $\mathrm{~S} \times \mathrm{G}^{3}$ \\
\hline \multicolumn{9}{|l|}{$\mathrm{DM}$} \\
\hline Intake, $\mathrm{kg} / \mathrm{d}$ & 23.6 & 25.5 & 25.2 & 24.9 & 1.0 & 0.40 & 0.18 & 0.07 \\
\hline \multicolumn{9}{|l|}{ Apparent total tract digestion } \\
\hline $\mathrm{kg} / \mathrm{d}$ & 16.8 & 17.5 & 18.1 & 17.2 & 0.64 & 0.30 & 0.83 & 0.11 \\
\hline$\%$ & 73.2 & 70.4 & 74.8 & 71.1 & 1.3 & 0.35 & 0.01 & 0.73 \\
\hline \multicolumn{9}{|l|}{$\mathrm{OM}$} \\
\hline Intake, $\mathrm{kg} / \mathrm{d}$ & 21.5 & 23.4 & 22.8 & 22.8 & 1.0 & 0.53 & 0.15 & 0.14 \\
\hline Digestible OMI, kg/d & 17.9 & 19.5 & 19.5 & 19.5 & 0.8 & 0.15 & 0.16 & 0.16 \\
\hline \multicolumn{9}{|l|}{ Apparent ruminal digestion } \\
\hline $\mathrm{kg} / \mathrm{d}$ & 9.62 & 7.43 & 9.13 & 7.98 & 1.1 & 0.98 & 0.11 & 0.61 \\
\hline$\%$ & 44.8 & 31.4 & 40.7 & 35.2 & 4.4 & 0.97 & 0.04 & 0.36 \\
\hline \multicolumn{9}{|l|}{ True ruminal digestion } \\
\hline $\mathrm{kg} / \mathrm{d}$ & 14.3 & 14.7 & 15.0 & 13.8 & 1.0 & 0.92 & 0.53 & 0.18 \\
\hline$\%$ & 66.7 & 63.1 & 66.2 & 60.5 & 3.3 & 0.59 & 0.11 & 0.71 \\
\hline Passage to duodenum, $\mathrm{kg} / \mathrm{d}$ & 11.9 & 16.1 & 13.7 & 14.8 & 1.2 & 0.81 & 0.04 & 0.21 \\
\hline \multicolumn{9}{|l|}{ Apparent postruminal digestion } \\
\hline $\mathrm{kg} / \mathrm{d}$ & 6.42 & 9.31 & 8.07 & 8.34 & 1.0 & 0.74 & 0.14 & 0.21 \\
\hline$\%$ of intake & 29.7 & 40.3 & 35.1 & 37.0 & 4.3 & 0.79 & 0.13 & 0.28 \\
\hline$\%$ of duodenal passage & 53.7 & 56.2 & 59.4 & 56.3 & 3.0 & 0.27 & 0.90 & 0.29 \\
\hline \multicolumn{9}{|l|}{ Apparent total tract digestion } \\
\hline $\mathrm{kg} / \mathrm{d}$ & 16.0 & 16.7 & 17.2 & 16.3 & 0.62 & 0.41 & 0.85 & 0.12 \\
\hline$\%$ & 74.5 & 71.6 & 75.8 & 72.1 & 1.2 & 0.45 & 0.01 & 0.76 \\
\hline
\end{tabular}

${ }^{1}$ Main effect of corn silage hybrid.

${ }^{2}$ Main effect of ground corn grain endosperm type.

${ }^{3}$ Interaction of corn silage hybrid and ground corn grain endosperm type.

tionally, digestibility of DM and OM were not affected by corn silage treatment. This is consistent with other recent experiments with lactating cows comparing $b m 3$ and a conventional corn silage (Oba and Allen, 1999; Oba and Allen, 2000b; Greenfield et al., 2001; Qiu et al., 2003). Although treatment effects on total tract digestibility of DM and OM have been consistent, effects on site of DM and OM digestion have not. Oba and Allen (2000b) reported that $b m 3$ corn silage compared with control corn silage did not affect total tract OM digestibility but reduced ruminal OM digestibility and increased postruminal OM digestibility when fed in low (29\%) or high (38\%) NDF diets to dairy cows in early lactation (70 DIM). Opposite effects of treatment on ruminal digestibility occurred in a study using latelactation cows (221 DIM); bm3 corn silage increased ruminal DM digestibility and tended to increase ruminal OM digestibility compared with control corn silage (Greenfield et al., 2001). Although there were differences in ruminal digestion of $\mathrm{DM}$ and $\mathrm{OM}$ in these studies, postruminal digestion entirely compensated so that total tract $\mathrm{OM}$ digestion was not affected. The current experiment found that $\mathrm{bm} 3$ corn silage, compared with control corn silage, did not affect ruminal, postruminal, or total tract apparent OM digestibility which is similar to results reported by Qiu et al. (2003). Differences in effects of treatment on digestibility of DM and $\mathrm{OM}$ among these experiments might be partially because of differences in feed intake response. Oba and Allen (1999) reported that response for total tract digestibility of DM to bm3 corn silage compared with its isogenic control corn silage was inversely related to response in DMI. There was no overall response to treatment of DM digestibility but response ranged from an increase of $\sim 5$ units to a decrease of $\sim 5$ units in DM digestibility that was linearly related to their response in DMI.

Total tract DM digestibility was higher for floury vs. vitreous corn grain $(P<0.01$; Table 4$)$. Although floury corn grain increased apparent ruminal OM digestibility 9.5 percentage units vs. vitreous grain $(P<0.04)$, slightly higher duodenal flow of microbial OM in vitreous diets reduced the differences between endosperm types so that truly ruminally degraded OM did not differ among treatments. Truly ruminally degraded OM averaged $14.5 \mathrm{~kg} / \mathrm{d}$ and is among the highest reported in literature, primarily because animals in this experiment averaged OM intake of $22.6 \mathrm{~kg} / \mathrm{d}$ and were producing $40 \mathrm{~kg} / \mathrm{d}$ of milk. Postruminal OM digestibility did not differ among treatments but increases of ruminal OM digestion in diets with floury endosperm resulted in greater total tract apparent $\mathrm{OM}$ digestion $(P<0.01)$.

\section{Site of Starch Digestion}

Contrary to our hypothesis, no interactions of main treatment effects occurred to affect starch digestion. 
Table 5. Effects of corn grain endosperm type and brown midrib 3 corn silage on digestion of starch.

\begin{tabular}{|c|c|c|c|c|c|c|c|c|}
\hline & \multicolumn{2}{|c|}{ Control } & \multicolumn{2}{|c|}{$b m 3$} & \multirow[b]{2}{*}{ SEM } & \multicolumn{3}{|c|}{$P$} \\
\hline & Floury & Vitreous & Floury & Vitreous & & $\mathrm{S}^{1}$ & $\mathrm{G}^{2}$ & $\mathrm{~S} \times \mathrm{G}^{3}$ \\
\hline Intake, $\mathrm{kg} / \mathrm{d}$ & 6.90 & 7.63 & 7.15 & 7.28 & 0.3 & 0.79 & 0.04 & 0.15 \\
\hline \multicolumn{9}{|l|}{ Apparent ruminal digestion } \\
\hline $\mathrm{kg} / \mathrm{d}$ & 4.26 & 2.28 & 3.75 & 3.04 & 0.7 & 0.82 & 0.03 & 0.27 \\
\hline$\%$ & 61.5 & 29.0 & 52.5 & 40.9 & 8.6 & 0.84 & 0.01 & 0.17 \\
\hline \multicolumn{9}{|l|}{ True ruminal digestion } \\
\hline $\mathrm{kg} / \mathrm{d}$ & 4.59 & 3.64 & 4.13 & 3.40 & 0.55 & 0.27 & 0.01 & 0.72 \\
\hline$\%$ & 66.4 & 46.8 & 57.7 & 45.8 & 6.0 & 0.27 & 0.002 & 0.38 \\
\hline Passage to duodenum, kg/d & 2.65 & 5.36 & 3.40 & 4.23 & 0.66 & 0.76 & 0.01 & 0.14 \\
\hline \multicolumn{9}{|l|}{ Apparent postruminal digestion } \\
\hline $\mathrm{kg} / \mathrm{d}$ & 2.43 & 4.74 & 3.07 & 3.57 & 0.67 & 0.66 & 0.03 & 0.15 \\
\hline$\%$ of intake & 35.4 & 63.2 & 43.1 & 50.4 & 8.8 & 0.73 & 0.03 & 0.18 \\
\hline$\%$ of duodenal passage & 90.9 & 83.5 & 90.6 & 83.6 & 3.6 & 0.96 & 0.01 & 0.91 \\
\hline \multicolumn{9}{|l|}{ Apparent total tract digestion } \\
\hline $\mathrm{kg} / \mathrm{d}$ & 6.69 & 7.02 & 6.82 & 6.63 & 0.27 & 0.47 & 0.70 & 0.17 \\
\hline$\%$ & 96.9 & 92.1 & 95.6 & 91.3 & 0.78 & 0.08 & $<0.001$ & 0.66 \\
\hline
\end{tabular}

${ }^{1}$ Main effect of corn silage hybrid.

${ }^{2}$ Main effect of ground corn grain endosperm type.

${ }^{3}$ Interaction of corn silage hybrid and ground corn grain endosperm type.

Although previous research from our laboratory found that $\mathrm{bm} 3$ corn silage reduced ruminal and total tract starch digestibility (Oba and Allen, 2000b), in the present experiment, $b m 3$ corn silage did not affect ruminal starch digestibility and only tended to reduce total tract starch digestibility compared with control corn silage $(P<0.08$; Table 5). However, endosperm type of corn grain caused substantial changes in site of starch digestion. Apparent ruminal digestibility of starch increased from 35.0 to $57.0 \%$ when vitreous corn grain was replaced by floury endosperm grain $(P<0.01)$. An experiment by Philippeau et al. (1999b) showed that apparent ruminal starch digestibility increased from 34.8 to $60.8 \%$ when flint corn was replaced by dent corn in diets of steers. Corn grain with floury endosperm also increased true ruminal starch digestibility compared with vitreous grain $(P<0.002)$. Differences among treatments were even greater for apparent vs. true ruminal starch digestibility because of the greater contribution of microbial starch to duodenal starch content in the diet containing vitreous corn grain and control corn silage compared with other diets. As expected, vitreous grain shifted the primary site of starch digestion to the intestines; postruminal starch digestibility as a percentage of intake was greater for vitreous vs. floury corn grain (56.8 vs. $39.3 \% ; P<0.03$ ). However, as a percentage of duodenal starch flow, starch digestibility was lower for vitreous grain compared with floury corn grain ( 83.6 vs. $90.8 \% ; P<0.01$ ). This indicates that corn grain with vitreous endosperm is less digestible than floury grain in the rumen and that the starch that passes from the rumen is slightly less digestible for vitreous grain. Substantial postruminal compensatory digestion occurred in vitreous grain diets; despite a $39 \%$ reduction in apparent ruminal starch digestibility and slightly lower postruminal starch digestibility as a percentage of duodenal flow, total tract starch digestibility was only $5 \%$ less for vitreous compared with floury grain diets.

Ruminal starch digestibility was greater for floury corn grain treatments because starch in floury endosperm digested at a rate of $21.9 \%$ per h vs. $12.9 \%$ per $\mathrm{h}$ for vitreous endosperm $(P<0.01$; Table 6$)$. Philippeau et al. (1999a) reported that dent hybrids (51.4\% vitreous) degraded faster than flint (71.8\% vitreous) hybrids in situ $(P<0.0001)$. Starch in floury endosperm is associated with a digestible protein matrix that is easily degraded by ruminal bacteria (Kotarski et al., 1992). In contrast, starch granules in vitreous endosperm are embedded in a protein matrix that can resist enzyme hydrolysis (Rooney and Plugfelder, 1986). Vitreous protein matrix is more resistant to digestion because ruminal bacteria digest zein proteins more slowly than glutelin proteins (Romagnolo et al., 1994), and vitreousness of corn grain is positively correlated with concentration of zein protein and negatively correlated with true glutelin protein concentration in corn grain (Philippeau et al., 2000). Because the protein matrix in floury endosperm is more easily hydrolyzed, greater microbial penetration of the starch granule occurs to increase rate of starch digestion. In this experiment, vitreousness (\% of total endosperm) of corn grain was 3.0 and $67.2 \%$ for floury and vitreous hybrids, respectively (Table 2), which represents the 2 extreme endosperm compositions of corn hybrids commercially available in the United States. Additionally, these corn grain treatments were selected based on their wide range of in vitro starch degradability, which was 7.7 and $1.8 \%$ 
TAYLOR AND ALLEN

Table 6. Effects of corn grain endosperm type and brown midrib 3 corn silage on ruminal digestion kinetics.

\begin{tabular}{|c|c|c|c|c|c|c|c|c|}
\hline & \multicolumn{2}{|c|}{ Control } & \multicolumn{2}{|c|}{$b m 3$} & \multirow[b]{2}{*}{ SEM } & \multicolumn{3}{|c|}{$P$} \\
\hline & Floury & Vitreous & Floury & Vitreous & & $\mathrm{S}^{1}$ & $\mathrm{G}^{2}$ & $\mathrm{~S} \times \mathrm{G}^{3}$ \\
\hline \multicolumn{9}{|c|}{ Ruminal digestion rate, $\% / \mathrm{h}$} \\
\hline Starch & 24.8 & 11.9 & 19.0 & 13.8 & 3.6 & 0.55 & 0.01 & 0.25 \\
\hline \multicolumn{9}{|c|}{ Ruminal passage rate, $\% / \mathrm{h}$} \\
\hline $\mathrm{pdNDF}^{4^{2}}$ & 2.58 & 2.58 & 2.37 & 2.68 & 0.52 & 0.92 & 0.77 & 0.78 \\
\hline $\mathrm{iNDF}^{5}$ & 3.26 & 3.01 & 3.29 & 3.52 & 0.27 & 0.27 & 0.94 & 0.34 \\
\hline Starch & 16.6 & 24.0 & 15.7 & 18.3 & 3.1 & 0.27 & 0.10 & 0.43 \\
\hline Liquid $^{6}$ & 18.0 & 20.4 & 20.6 & 20.6 & 2.0 & 0.46 & 0.53 & 0.54 \\
\hline \multicolumn{9}{|c|}{ Ruminal turnover rate, $\% / \mathrm{h}$} \\
\hline $\mathrm{DM}$ & 10.3 & 9.44 & 9.58 & 10.3 & 0.80 & 0.92 & 0.93 & 0.33 \\
\hline $\mathrm{OM}$ & 9.84 & 9.11 & 9.19 & 9.91 & 0.80 & 0.92 & 0.99 & 0.35 \\
\hline NDF & 4.57 & 4.32 & 4.46 & 4.93 & 0.44 & 0.54 & 0.78 & 0.39 \\
\hline $\mathrm{pdNDF}^{4}$ & 5.88 & 5.58 & 5.16 & 5.88 & 0.64 & 0.72 & 0.72 & 0.39 \\
\hline $\mathrm{iNDF}^{5}$ & 3.26 & 3.01 & 3.29 & 3.52 & 0.27 & 0.27 & 0.94 & 0.34 \\
\hline Starch & 41.4 & 36.3 & 34.8 & 31.9 & 3.6 & 0.14 & 0.28 & 0.76 \\
\hline
\end{tabular}

${ }^{1}$ Main effect of corn silage hybrid.

${ }^{2}$ Main effect of ground corn grain endosperm type.

${ }^{3}$ Interaction of corn silage hybrid and ground corn grain endosperm type.

${ }^{4} \mathrm{pdNDF}=$ Potentially digestible NDF.

${ }^{5} \mathrm{iNDF}=$ Indigestible NDF.

${ }^{6}$ Measured using Co-EDTA.

Table 7. Effects of corn grain endosperm type and brown midrib 3 corn silage on digestion of total NDF and potentially digestible NDF.

\begin{tabular}{|c|c|c|c|c|c|c|c|c|}
\hline & \multicolumn{2}{|c|}{ Control } & \multicolumn{2}{|c|}{ bm3 } & \multirow[b]{2}{*}{ SEM } & \multicolumn{3}{|c|}{$P$} \\
\hline & Floury & Vitreous & Floury & Vitreous & & $S^{1}$ & $\mathrm{G}^{2}$ & $\mathrm{~S} \times \mathrm{G}^{3}$ \\
\hline \multicolumn{9}{|l|}{ NDF } \\
\hline Intake, $\mathrm{kg} / \mathrm{d}$ & 5.74 & 6.21 & 6.09 & 6.00 & 0.3 & 0.71 & 0.29 & 0.13 \\
\hline \multicolumn{9}{|l|}{ Apparent ruminal digestion } \\
\hline $\mathrm{kg} / \mathrm{d}$ & 2.14 & 2.22 & 2.45 & 2.39 & 0.21 & 0.21 & 0.97 & 0.72 \\
\hline$\%$ & 37.4 & 34.8 & 41.0 & 40.2 & 3.3 & 0.20 & 0.61 & 0.79 \\
\hline Passage to duodenum, $\mathrm{kg} / \mathrm{d}$ & 3.60 & 4.01 & 3.64 & 3.62 & 0.27 & 0.51 & 0.45 & 0.42 \\
\hline \multicolumn{9}{|l|}{ Apparent postruminal digestion } \\
\hline $\mathrm{kg} / \mathrm{d}$ & 0.52 & 0.57 & 0.70 & 0.54 & 0.18 & 0.68 & 0.77 & 0.57 \\
\hline$\%$ of intake & 8.95 & 9.96 & 11.5 & 9.60 & 3.0 & 0.71 & 0.88 & 0.62 \\
\hline$\%$ of duodenal passage & 14.2 & 14.2 & 19.7 & 14.9 & 4.2 & 0.44 & 0.55 & 0.54 \\
\hline \multicolumn{9}{|l|}{ Apparent total tract digestion } \\
\hline $\mathrm{kg} / \mathrm{d}$ & 2.66 & 2.80 & 3.15 & 2.90 & 0.13 & 0.04 & 0.69 & 0.16 \\
\hline$\%$ & 46.3 & 45.3 & 52.4 & 49.7 & 2.1 & 0.02 & 0.37 & 0.68 \\
\hline \multicolumn{9}{|l|}{ Potentially digestible NDF } \\
\hline Intake, $\mathrm{kg} / \mathrm{d}$ & 3.75 & 4.03 & 4.45 & 4.40 & 0.19 & 0.001 & 0.38 & 0.22 \\
\hline \multicolumn{9}{|l|}{ Apparent ruminal digestion } \\
\hline $\mathrm{kg} / \mathrm{d}$ & 2.14 & 2.22 & 2.45 & 2.39 & 0.21 & 0.21 & 0.97 & 0.72 \\
\hline$\%$ & 57.1 & 53.0 & 55.8 & 54.8 & 4.7 & 0.97 & 0.60 & 0.75 \\
\hline Passage to duodenum, $\mathrm{kg} / \mathrm{d}$ & 1.61 & 1.84 & 2.00 & 2.00 & 0.23 & 0.25 & 0.61 & 0.63 \\
\hline \multicolumn{9}{|l|}{ Apparent postruminal digestion } \\
\hline $\mathrm{kg} / \mathrm{d}$ & 0.52 & 0.57 & 0.70 & 0.54 & 0.18 & 0.68 & 0.77 & 0.57 \\
\hline$\%$ of intake & 13.6 & 15.4 & 15.6 & 13.0 & 4.4 & 0.95 & 0.92 & 0.60 \\
\hline$\%$ of duodenal passage & 30.8 & 28.6 & 36.1 & 25.1 & 7.4 & 0.90 & 0.33 & 0.51 \\
\hline \multicolumn{9}{|l|}{ Apparent total tract digestion } \\
\hline $\mathrm{kg} / \mathrm{d}$ & 2.66 & 2.80 & 3.15 & 2.90 & 0.13 & 0.04 & 0.69 & 0.16 \\
\hline$\%$ & 70.7 & 69.0 & 71.3 & 67.4 & 2.8 & 0.85 & 0.31 & 0.68 \\
\hline \multicolumn{9}{|l|}{ Indigestible NDF } \\
\hline Intake, $\mathrm{kg} / \mathrm{d}$ & 1.99 & 2.18 & 1.64 & 1.59 & 0.10 & $<0.001$ & 0.23 & 0.07 \\
\hline
\end{tabular}

${ }^{1}$ Main effect of corn silage hybrid.

${ }^{2}$ Main effect of ground corn grain endosperm type.

${ }^{3}$ Interaction of corn silage hybrid and ground corn grain endosperm type. 
per $\mathrm{h}$ for the floury and vitreous hybrids, respectively (Table 2). The much wider range in rate of starch digestion observed in vitro than observed in vivo indicates that in vitro starch digestibility assay is a useful tool in estimating only the relative changes in ruminal starch digestion rates.

Corn grain with vitreous endosperm tended to increase ruminal passage rate of starch ( 21.2 vs. $16.2 \%$ per h; $P<0.10$; Table 6 ). We thought that floury corn grain might disperse in the liquid fraction and possibly increase rate of starch passage from the rumen. However, rate of starch passage from the rumen and ruminal liquid passage rate (mean $\sim 20 \%$ per $\mathrm{h}$ ) were not correlated across cow period means $(\mathrm{r}=0.03 ; P<0.86)$. Faster ruminal starch passage rate in this experiment is likely because of greater density of vitreous corn grain; more vitreous flint corn grain was more dense than less vitreous dent corn grain (Philippeau et al., 1999a), and greater particle density decreases mean ruminal retention time (Lechner-Doll et al., 1991). Faster rate of starch digestion and a tendency for slower rate of ruminal starch passage for floury corn grain vs. vitreous grain resulted in a lack of treatment effects on ruminal starch turnover rate.

It is unclear when shifting starch digestion from the rumen to the intestines might benefit milk production. Small intestinal digestion of starch to glucose is theoretically more efficient than ruminal fermentation to VFA (Owens et al., 1986), and although glucose availability might increase with greater intestinal starch flow, milk production does not necessarily increase (Knowlton et al., 1998; Arieli et al., 2001; Reynolds et al., 2001). As greater amounts of concentrate are included in ruminant diets, understanding limits to starch digestion and absorption in the intestines of ruminants has become a question of interest. A linear response in net portal glucose absorption was observed for abomasal infusions of glucose but a quadratic response in net portal glucose absorption was observed for abomasal infusions of cornstarch; diminished absorption occurred with greater amounts of cornstarch infusion (Kreikemeier et al., 1991). This suggests that limitations to small intestinal starch use are from starch digestion and not glucose absorption. Huntington (1997) suggested that limitations to small intestinal starch digestion are because of less secretion of effective pancreatic amylase with greater duodenal starch flow. However, Oba and Allen (2003b) found that postruminal starch digestibility (\% of duodenal flow) increased as duodenal starch flow increased $(\mathrm{r}=0.49 ; P<0.05)$. They suggested that limitations to starch use by pancreatic enzyme activity would be expected to decrease intestinal starch digestibility as duodenal flow of starch increased, and concluded that digestibility of starch particles escaping the rumen may be more dependent on physical and chemical characteristics of the starch particles than limited pancreatic enzyme activity. In this experiment, the relationship between postruminal starch digestibility and duodenal starch flow was not significant, but in agreement with Oba and Allen (2003b), it was not negative $(\mathrm{r}=0.23 ; P<0.20)$. Characteristics of starch particles escaping ruminal digestion may be a primary limitation to starch digestion in the small intestine in addition to other factors.

Ruminal and postruminal starch digestibility ranges widely for a variety of feedstuffs, but intestinal starch digestion often compensates for reductions in ruminal starch digestion so that variation in total tract starch digestibility is relatively small (Huntington, 1997). However, greater intestinal starch flow may decrease efficiency of energy use for productive purposes. Abomasal infusion of increasing amounts of cornstarch increased ileal concentrations of starch and glucose (Kreikemeier et al., 1991) and greater starch flow to the intestines might increase large intestinal fermentation of starch to VFA. Although much of this energy can be absorbed and used by the cow, microbial OM from large intestinal fermentation is lost in the feces. Additionally, even if increasing starch flow and intestinal digestion results in greater uptake of glucose by the gut, the energy might not be used toward milk production but instead might be oxidized or retained if the animal is in positive energy balance (Lemosquet et al., 1997; Knowlton et al., 1998; Reynolds et al., 2001). Knowlton et al. (1998) observed that infusing starch hydrolysate in the abomasum vs. the rumen increased blood $\mathrm{CO}_{2}$ from glucose by $93 \%(P<0.001)$. Duodenal glucose infusions increased energy balance without affecting milk yield because of greater plasma insulin concentrations (Lemosquet et al., 1997). The shift of starch digestion from the rumen to the intestines observed in vitreous corn grain diets tended to increase the plasma insulin:glucagon ratio $(P<0.07$; Taylor and Allen, 2005a), which might decrease the rate of gluconeogenesis and increase oxidation of fuels in the liver, causing satiety (Allen, 2000).

Inconsistencies with shifting digestion to the intestines coupled with requirements of microbes for fermentable carbohydrate have led many to conclude that extensive ruminal starch fermentation is often more beneficial than intestinal digestion (Huntington, 1997). Ruminal fermentation of starch can increase ruminal propionate production and theoretically could increase substrate available for gluconeogenesis. However, DMI can also be limited by propionate; Oba and Allen (2003c) speculated that if temporal flux of propionate to the liver is greater than glucose demand, satiety could occur by oxidation of propionate and other metabolic fuels 
in the tricarboxylic acid cycle. Corn grain with floury endosperm was fermented faster and to a greater extent in the rumen, and depressed DMI when combined with control corn silage possibly because of oxidation of fuels, but did not limit DMI when combined with bm3 corn silage probably because of a concurrent increase in milk production (Taylor and Allen, 2005a).

It is unlikely that the optimal fraction of starch digested in the rumen is constant across all diets and animals. Postruminal starch digestion could theoretically increase glucose availability but could also decrease gluconeogenesis and increase tissue uptake. $\mathrm{Ru}-$ minal starch digestion can increase glucose precursors but can limit meal size and DMI if fuels are oxidized in the liver. Microbial protein production is integrally tied with starch digestion and probably plays an important role in animal response to site of starch digestion. The response of any given animal is likely to vary considerably and will depend on energy balance, stage of lactation, hormone responsiveness, and nutrition. Therefore, the optimum site of starch digestion for lactating dairy cows depends on a variety of factors and response is difficult to predict.

\section{Fiber Digestion}

Contrary to our hypothesis, no interactions of main treatment effects were observed for digestibility of NDF, pdNDF (Table 7), or ruminal digestion kinetics of pdNDF (Table 6). Corn grain with floury endosperm and $b m 3$ corn silage were expected to reduce rate of ruminal pdNDF digestion by reducing ruminal $\mathrm{pH}$, but pdNDF digestion rate was not affected by either floury endosperm grain or bm 3 corn silage (Table 6). Although mean $\mathrm{pH}$ was lower for corn grain with floury endosperm and bm3 corn silage (Taylor and Allen, 2005b), $\mathrm{pH}$ might not have been low enough to substantially affect pdNDF digestion. Substantial rates of cellulose digestion can occur in vitro at $\mathrm{pH}$ less than 6.0 and it is not until $\mathrm{pH}$ drops below 5.3 that lysis or detachment of cellulolytic bacteria occurs (Mouriño et al., 2001). In vitro, rate of pdNDF digestion can be inhibited by the presence of starch regardless of $\mathrm{pH}$ (Grant and Mertens, 1992). This is supported in vivo; reducing steam-flaked corn density $(\mathrm{kg} / \mathrm{L})$ increased ruminal starch digestibility (linear $P<0.05$ ) and reduced ruminal ADF digestibility (linear $P<0.01$ ) without affecting ruminal $\mathrm{pH}$ (Plascencia and Zinn, 1996). In contrast, previous work in our laboratory reported no relationship between the digestion rate of pdNDF and amount of ruminally degraded starch (Oba and Allen, 2003b). Similarly, increased rate of starch digestion did not affect NDF digestion rate in situ (Callison et al., 2001). Variation across experiments in the inhibition of pdNDF digestion by starch digestion independent of ruminal $\mathrm{pH}$ suggests that other factors such as accumulation of fermentation end products are likely involved.

Interestingly, ruminal starch digestibility and ruminal pdNDF digestibility were positively correlated across cow period means in this experiment $(\mathrm{r}=0.49$; $P<0.007$ ). Extensive interaction occurs among ruminal microorganisms and it is possible that this positive relationship between starch and fiber digestibility represents microbial synergy and cross feeding. Mixed cultures of cellulolytic and noncellulolytic bacteria increased cellulose disappearance in vitro more than pure cultures of 3 predominant species of ruminal cellulolytic bacteria (Mouriño et al., 2001). Highly fermentable, high starch diets in vivo may not be as detrimental to microbial fiber digestion as in vitro experiments indicate.

Unlike a previous experiment from our laboratory (Oba and Allen, 2000b), ruminal passage rate of iNDF was not increased by $b m 3$ corn silage compared with control (Table 6). Other experiments reported no effect on ruminal passage rate of iNDF for $b m 3$ corn silage (Tjardes et al., 2000) or brown midrib sorghum (Aydin et al., 1999). Differences among these experiments are probably because of treatment effects on DMI and are probably related to the extent that ruminal distension limits intake. In this experiment, ruminal pool size mirrored treatment effects on DMI (Taylor and Allen, 2005a), which indicates that ruminal fill was probably not limiting to DMI. Additionally, range of DMI across treatments in this experiment was $1.9 \mathrm{~kg} / \mathrm{d}$, and may not have been large enough to significantly affect iNDF passage.

Consistent with the lack of treatment effects on rates of digestion and passage, no treatment effects were observed for turnover rate of pdNDF or iNDF. Additionally, although in vitro NDF digestibility was 12.6 units higher for $b m 3$ silage than control silage (Table 1), bm3 corn silage did not increase ruminal or postruminal pdNDF or NDF digestibility in vivo and only slightly increased total tract NDF digestibility $(P<0.02$; Table 6). Similarly, Oba and Allen (2000b) reported bm3 corn silage did not increase ruminal or total tract NDF digestibility; a greater rate of iNDF passage from the rumen for $b m 3$ corn silage was counteracted by a reduced rate of pdNDF digestion. However, in the present experiment, $b m 3$ corn silage did not affect rate of iNDF passage or rate of pdNDF digestion. These results suggest that although in vitro NDF digestibility can be improved by $b m 3$ corn silage, in vivo response is dependent upon integration of several factors. Dry matter intake and ruminal passage rate are important in determining ruminal residence time but are difficult to predict. Additionally, $\mathrm{pH}$ and starch digestion likely 
affect NDF digestibility in the rumen but mixed results from in vitro and in vivo experiments make it difficult to formulate any accurate predictions for animal response to diets. Perhaps most interesting is the apparent resiliency of the animal to changes in diet; changes in passage and digestion rates of nutrients as well as site of digestion can be compensated for so that total tract digestibility is often similar among treatments.

\section{CONCLUSIONS}

Floury endosperm improved total tract DM and OM digestibility because of increased starch digestibility. Contrary to our hypothesis, no interaction of treatments for any measure of starch or fiber digestion occurred. Vitreous corn grain fermented more slowly and passed from the rumen faster, resulting in decreased ruminal starch digestibility. Compensatory postruminal starch digestion in diets containing vitreous corn grain resulted in relatively small differences in total tract starch digestion compared with grain with floury endosperm. Greater ruminal starch digestion in floury grain diets and lower ruminal $\mathrm{pH}$ for floury grain and bm3 corn silage did not affect ruminal fiber digestion kinetics, and a positive relationship between ruminal starch and pdNDF digestibility suggests interactions among microbial populations in the rumen. Endosperm type of corn grain can affect digestion kinetics and site of starch digestion. Brown midrib corn silage slightly increased total tract NDF digestibility but did not affect rate of pdNDF digestion. This implies that greater in vitro NDF digestibility of brown midrib corn silage does not necessarily correspond with greater in vivo NDF digestibility.

\section{ACKNOWLEDGMENTS}

We wish to acknowledge Purina Mills, Inc., and Syngenta Seeds, Inc., for their financial support of this research. The authors thank N. K. Ames for performing duodenal and ruminal cannulations, and thank D. G. Main, Y. Ying, R. A. Longuski, C. S. Mooney, J. A. Voelker, K. J. Harvatine, B. J. Bradford, and R. E. Kreft for technical assistance and support.

\section{REFERENCES}

Allen, M. S. 2000. Effects of diet on short-term regulation of feed intake by lactating dairy cattle. J. Dairy Sci. 83:1598-1624.

Allen, M. S., L. E. Armentano, M. N. Pereira, and Y. Ying. 2000. Method to measure fractional rate of volatile fatty acid absorption from the rumen. 25th Conference on Rumen Function, Chicago, IL. Department of Animal Science, Michigan State University, East Lansing. http://www.msu.edu/user/rumen/index.htm.

American Society of Agricultural Engineers (ASAE). 1968. Method of determining and expressing fineness of feed material by sieving. ASAE Standard S319. ASAE, St. Joseph, MI.
Arieli, A., S. Abramson, S. J. Mabjeesh, S. Zamwel, and I. Bruckental. 2001. Effect of site and source of energy supplementation on milk yield in dairy cows. J. Dairy Sci. 84:462-470.

Aydin, G., R. J. Grant, and J. O'Rear. 1999. Brown midrib sorghum in diets for lactating dairy cows. J. Dairy Sci. 82:2127-2135.

Callison, S. L., J. L. Firkins, M. L. Eastridge, and B. L. Hull. 2001. Site of nutrient digestion by dairy cows fed corn of different particle sizes or steam-rolled. J. Dairy Sci. 84:1458-1467.

Crocker, L. M., E. J. DePeters, J. G. Fadel, H. Perez-Monti, S. J. Taylor, J. A. Wyckoff, and R. A. Zinn. 1998. Influence of processed corn grain in diets of dairy cows on digestion of nutrients and milk composition. J. Dairy Sci. 81:2394-2407.

Goering, H. K., and P. J. Van Soest. 1970. Forage Fiber Analysis (Apparatus, Reagents, Procedures, and Some Applications). Agric. Handbook No. 379. ARS-USDA, Washington, DC.

Grant, R. J., and D. R. Mertens. 1992. Influence of buffer $\mathrm{pH}$ and raw corn starch addition on in vitro fiber digestion kinetics. J. Dairy Sci. 75:2762-2768.

Greenfield, T. L., R. L. Baldwin, R. A. Erdman, and K. R. McLeod. 2001. Ruminal fermentation and intestinal flow of nutrients by lactating cows consuming brown midrib corn silages. J. Dairy Sci. 84:2469-2477.

Hach, C. C., B. K. Bowden, A. B. Lopelove, and S. V. Brayton. 1987. More powerful peroxide Kjeldahl digestion method. J. AOAC 70:783-787.

Huntington, G. B. 1997. Starch utilization by ruminants: From basics to the bunk. J. Anim. Sci. 75:852-867.

Karkalas, J. 1985. An improved enzymatic method for the determination of native and modified starch. J. Sci. Food Agric. 36:10191027.

Knowlton, K. F., T. E. Dawson, B. P. Glenn, G. B. Huntington, and R. A. Erdman. 1998. Glucose metabolism and milk yield of cows infused abomasally or ruminally with starch. J. Dairy Sci. 81:3248-3258.

Kotarski, S. F., R. D. Waniska, and K. K. Thurn. 1992. Starch hydrolysis by the ruminal microflora. J. Nutr. 122:178-190.

Kreikemeier, K. K., D. L. Harmon, R. T. Brandt, Jr., T. B. Avery, and D. E. Johnson. 1991. Small intestinal starch digestion in steers: Effect of various levels of abomasal glucose, corn starch and corn dextrin infusion on small intestinal disappearance and net glucose absorption. J. Anim. Sci. 69:328-338.

Lammers, B. P., D. R. Buckmaster, and A. J. Heinrichs. 1996. A simple method for the analysis of particle sizes of forage and total mixed rations. J. Dairy Sci. 79:922-928.

Lechner-Doll, M., M. Kaske, and W. Von Englehardt. 1991. Factors affecting the mean retention time of particles in the fore-stomachs of ruminants and camelids. Pages 455-482 in Physiological Aspects of Digestion and Metabolism in Ruminants. T. Tsuda, Y. Sasaki, and R. Kawashima, ed., Academic Press, New York, NY.

Lemosquet, S., N. Rideau, H. Rulquin, P. Faverdin, J. Simon, and R. Verite. 1997. Effects of a duodenal glucose infusion on the relationship between plasma concentrations of glucose and insulin in dairy cows. J. Dairy Sci. 80:2854-2865.

Mouriño, F., R. Akkarawongsa, and P. J. Weimer. 2001. Initial pH as a determinant of cellulose digestion rate by mixed ruminal microorganisms in vitro. J. Dairy Sci. 84:848-859.

National Research Council. 2001. Nutrient Requirements of Dairy Cattle. 7th rev. ed. National Academy Press, Washington, DC.

Oba, M., and M. S. Allen. 1999. Effects of brown midrib 3 mutation in corn silage on dry matter intake and productivity of high yielding dairy cows. J. Dairy Sci. 82:135-142.

Oba, M., and M. S. Allen. 2000a. Effects of brown midrib 3 mutation in corn silage on productivity of dairy cows fed two concentrations of dietary neutral detergent fiber: 1 . Feeding behavior and nutrient utilization. J. Dairy Sci. 83:1333-1341.

Oba, M., and M. S. Allen. 2000b. Effects of brown midrib 3 mutation in corn silage on productivity of dairy cows fed two concentrations of dietary neutral detergent fiber: 3 . Digestibility and microbial efficiency. J. Dairy Sci. 83:1350-1358.

Oba, M., and M. S. Allen. 2003a. Effects of corn grain conservation method on feeding behavior and productivity of lactating dairy 
cows at two dietary starch concentrations. J. Dairy Sci. 86:174-183.

Oba, M., and M. S. Allen. 2003b. Effects of corn grain conservation method on ruminal digestion kinetics for lactating dairy cows at two dietary starch concentrations. J. Dairy Sci. 86:184-194.

Oba, M., and M. S. Allen. 2003c. Extent of hypophagia caused by propionate infusion is related to plasma glucose concentration in lactating dairy cows. J. Nutr. 133:1105-1112.

Owens, F. N., R. A. Zinn, and Y. K. Kim. 1986. Limits to starch digestion in the ruminant small intestine. J. Dairy Sci. 63:1634-1648.

Philippeau, C., J. Landry, and B. Michalet-Doreau. 2000. Influence of the protein distribution of maize endosperm on ruminal starch degradability. J. Sci. Food Agric. 80:404-408.

Philippeau, C., F. Le Deschault de Monredon, and B. Michalet-Doreau. 1999a. Relationship between ruminal starch degradation and the physical characteristics of corn grain. J. Anim. Sci. 77:238-243.

Philippeau, C., C. Martin, and B. Michalet-Doreau. 1999b. Influence of grain source on ruminal characteristics and rate, site, and extent of digestion in beef steers. J. Anim. Sci. 77:1587-1596.

Plascencia, A., and R. A. Zinn. 1996. Influence of flake density on the feeding value of steam-processed corn in diets for lactating cows. J. Anim. Sci. 74:310-316.

Qiu, X., M. L. Eastridge, and Z. Wang. 2003. Effects of corn silage hybrid and dietary concentration of forage NDF on digestibility and performance by dairy cows. J. Dairy Sci. 86:3667-3674.

Reynolds, C. K., S. B. Cammell, D. J. Humphries, D. E. Beever, J. D. Sutton, and J. R. Newbold. 2001. Effects of postrumen starch infusion on milk production and energy metabolism in dairy cows. J. Dairy Sci. 84:2250-2259.

Robinson, P. H., C. J. Sniffen, and D. F. Smith. 1985. Development of a one-piece reentrant cannula for the proximal duodenum of dairy cows. J. Dairy Sci. 68:986-995.

Romagnolo, D., C. E. Polan, and W. E. Barbeau. 1994. Electrophoretic analysis of ruminal degradability of corn proteins. J. Dairy Sci. 77:1093-1099.

Rooney, L. W., and R. L. Plugfelder. 1986. Factors affecting starch digestibility with special emphasis on sorghum and corn. J. Anim. Sci. 63:1607-1623.

Taylor, C. C., and M. S. Allen. 2005a. Corn grain endosperm type and brown midrib 3 corn silage: Feeding behavior and milk yield of lactating cows. J. Dairy Sci. 88:1425-1433.

Taylor, C. C., and M. S. Allen. 2005b. Corn grain endosperm type and brown midrib 3 corn silage: Ruminal fermentation and $\mathrm{N}$ partitioning in lactating cows. J. Dairy Sci. 88:1434-1442.

Tjardes, K. E., D. D. Buskirk, M. S. Allen, N. K. Ames, L. D. Bourquin, and S. R. Rust. 2000. Brown midrib-3 corn silage improves digestion but not performance of growing beef steers. J. Anim. Sci. 78:2957-2965.

Van Soest, P. J., J. B. Robertson, and B. A. Lewis. 1991. Methods for dietary fiber, neutral detergent fiber and nonstarch polysaccharides in relation to animal nutrition. J. Dairy Sci. 74:35833597.

Williams, C. H., D. J. David, and O. Iismaa. 1962. The determination of chromic oxide in feces samples by atomic absorption spectrophotometry. J. Agric. Sci. 59:381-385. 